\title{
Anion inhibition studies of the fastest carbonic anhydrase (CA) known, the extremo-CA from the bacterium Sulfurihydrogenibium azorense
}

\author{
Daniela Vullo $^{\mathrm{a}}$, Viviana De Luca ${ }^{\mathrm{b}}$, Andrea Scozzafava ${ }^{\mathrm{a}}$, Vincenzo Carginale ${ }^{\mathrm{b}}$, Mosè Rossi ${ }^{\mathrm{b}, \mathrm{c}}$, \\ Claudiu T. Supuran ${ }^{\mathrm{a}, \mathrm{d}, *}$, Clemente Capasso ${ }^{\mathrm{b}, *}$ \\ ${ }^{a}$ Università degli Studi di Firenze, Polo Scientifico, Laboratorio di Chimica Bioinorganica, Rm. 188, Via della Lastruccia 3, 50019 Sesto Fiorentino (Florence), Italy \\ ${ }^{\mathrm{b}}$ Istituto di Biochimica delle Proteine-CNR, Via P. Castellino 111, 80131 Napoli, Italy \\ ${ }^{\mathrm{C}}$ Centro di Ricerca Interdipartimentale sui Biomateriali, Università Federico II, P-le V. Tecchio 80, 80125 Napoli, Italy \\ ${ }^{\mathrm{d}}$ Università degli Studi di Firenze, Polo Scientifico, Dipartimento di Scienze Farmaceutiche, Via Ugo Schiff 6, 50019 Sesto Fiorentino (Florence), Italy
}

\section{A R T I C L E I N F O}

\section{Article history:}

Received 11 September 2012

Accepted 18 September 2012

Available online 27 September 2012

\section{Keywords:}

Carbonic anhydrase

Anion

Alpha-class enzyme

Inhibitor

Sulfurihydrogenibium azorense

Extremophilic bacteria

\begin{abstract}
A B S T R A C T
The $\alpha$-carbonic anhydrase (CA, EC 4.2.1.1) from the extremophilic bacterium Sulfurihydrogenibium azorense, SazCA, is the fastest CA known to date as a catalyst for $\mathrm{CO}_{2}$ hydration to bicarbonate and protons. We report an inhibition study of this enzyme with inorganic anions and several other small molecules known to interact with these metalloenzymes. Bicarbonate, carbonate and sulfate were ineffective SazCA inhibitors whereas most other inorganic anions were submillimolar inhibitors. The best inhibition was observed with trithiocarbonate, diethyldithiocarbamate, sulfamide, sulfamate, phenylboronic, and phenylarsonic acid, which showed inhibition constants in the range of 3-39 $\mu \mathrm{M}$. As SazCA is very stable at high temperatures (being an 'extremo-CA') and very effective as a catalyst, the inhibition studies reported here may be crucial for designing biotechnological applications for this enzyme, for example for $\mathrm{CO}_{2}$ capture processes.
\end{abstract}

(c) 2012 Elsevier Ltd. All rights reserved.
We have recently reported the discovery and characterization of an $\alpha$-carbonic anhydrase (CA, EC 4.2.1.1) from the extremophilic bacterium Sulfurihydrogenibium yellowstonense YO3AOP1, enominated SspCA. ${ }^{1,2}$ The genus Sulfurihydrogenibium comprises chemolithotrophic bacteria able to survive in extremely harsh conditions of temperature (up to $110^{\circ} \mathrm{C}$ ) and in the presence of high concentrations of hydrogensulfide (between 1 and $100 \mathrm{M}$ ) or other sulfur-containing inorganic anions., ${ }^{3,4}$ As its name indicates, S. yellowstonense has been discovered in the Yellowstone National Park several years ago. ${ }^{3}$ A related species, S. azorense, was subsequently discovered in the Azores Islands. ${ }^{4}$ As CAs act as very effective catalysts for the conversion of $\mathrm{CO}_{2}$ to bicarbonate, ${ }^{5-8}$ it is very probable that the enzymes present in these bacteria are involved in the $\mathrm{CO}_{2}$ fixation and other biosynthetic processes (e.g., carboxylations), as for other organisms, such as bacteria, diatoms, algae and plants, in which the role of the various classes of CAs is well established. ${ }^{4-8}$

Indeed, CAs, of which five genetically distinct families are known to date, are present in organisms all over the phylogenetic tree and involved in a variety of physiologic processes related to

\footnotetext{
* Corresponding authors. Tel.: +39 055 4573005; fax: +39 0554573385 (C.T.S.); tel.: +39081 6132559; fax: +390816132712 (C.C.).

E-mail addresses: claudiu.supuran@unifi.it (C.T. Supuran), c.capasso@ibp.cnr.it (C. Capasso).
}

$\mathrm{pH}$ homeostasis, secretion of electrolytes, biosynthetic processes, etc. $^{5-8}$ Ultimately, many CAs started to be considered for biotechnological applications of enzymatic $\mathrm{CO}_{2}$ capture, due to the enhanced emission of green gases among which $\mathrm{CO}_{2}$ is one of the main components. ${ }^{9-11}$ Indeed, by effectively catalyzing the conversion of $\mathrm{CO}_{2}$ to bicarbonate, which is thereafter either eliminated or precipitated from the system, such enzymes may lead to the capture/sequestration of $\mathrm{CO}_{2}$ from combustion gases, and alleviate the global warming effects through a reduction of $\mathrm{CO}_{2}$ emissions in the atmosphere. One of the main problems of such biotechnological processes is the lack of stability of most such enzymes of mammalian origin to repeated cycles of $\mathrm{CO}_{2}$ capture, when various denaturating conditions may be encountered, such as high temperature, high concentrations of salts (among others carbonate and bicarbonate generated through the catalyzed reaction), etc. This is one of the reasons why CAs present in the genome of extremophilic bacteria started to be investigated in some detail ultimately, as SspCA, the enzyme mentioned above from S. yellowstonense, ${ }^{1,2}$ as well as the $\alpha$-CA from Thiomicrospira crunogena, another sulfur-oxidizing chemolithoautotrophic bacterium, recently investigated by McKenna's group. ${ }^{12}$ Such enzymes show greater stability at higher temperatures, and some of them also were highly catalytically active for the physiologic reaction, that is, hydration of $\mathrm{CO}_{2}$ to bicarbonate and protons. ${ }^{1,2}$ For example, SspCA showed a $k_{\text {cat }} / K_{\mathrm{m}}$ value of $1.1 \times 10^{8} \mathrm{M}^{-1} \times \mathrm{s}^{-1}$ (at $20^{\circ} \mathrm{C}$ and $\mathrm{pH}$ of 
7.5 ) being thus $73.3 \%$ as active as the human (h) isoform hCA II, one of the best catalysts known in nature $\left(k_{\text {cat }} / K_{\mathrm{m}}\right.$ value of $1.51 \times 10^{8} \mathrm{M}^{-1}$ $\times \mathrm{S}^{-1}$, in the same conditions)..$^{1,2}$

By translated genome inspection of $S$. azorense, we identified a gene encoding an $\alpha$-CA also in this bacterium, which we denominate SazCA, which is the homolog of SspCA, previously characterized in S. yellowstonense. ${ }^{1,2}$ Here we report the first study on this enzyme, measuring its catalytic activity for the physiologic reaction, that is, $\mathrm{CO}_{2}$ hydration to bicarbonate and protons, as well as its inhibition profile with anions and similar small molecules known to bind to the zinc ion in metalloproteins. ${ }^{13-16}$

Data of Table 1 show that SazCA has the highest catalytic activity for the physiologic reaction $\left(\mathrm{CO}_{2}\right.$ hydration to bicarbonate and protons) of all known to date CAs, with the following kinetic parameters: $k_{\text {cat }}$ of $4.4 \times 10^{6} \mathrm{~s}^{-1}, K_{\mathrm{m}}$ of $12.5 \mathrm{mM}$ and $k_{\text {cat }} / K_{\mathrm{m}}$ of $3.5 \times 10^{8} \mathrm{M}^{-1} \times \mathrm{s}^{-1}$ (at $20^{\circ} \mathrm{C}$ and $\mathrm{pH}$ of 7.5 ) being thus 2.33 times more active than the human (h) isoform hCA II, one of the best catalysts known in nature. ${ }^{1,2}$ Furthermore, SazCA was 3.2 times more effective as a catalyst for the physiologic reaction compared to a similar bacterial enzyme, SspCA investigated earlier by us, ${ }^{1,2}$ and 7-times more effective compared to the slow human isofom hCA $\mathrm{I}^{1,2}$ (Table 1 ). All these enzymes (except hCA I) were effectively inhibited by the sulfonamide in clinical use acetazolamide (5-acetamido-1,3,4-thiadiazole-2-sulfonamide), with inhibition constants in the range of $0.9-12 \mathrm{nM}$ (the $K_{\mathrm{I}}$ of this sulfonamide against hCA I was of $250 \mathrm{nM}$ ). It may be observed that acetazolamide is an excellent, subnanomolar inhibitor of SazCA, being much more effective against this isoform than against hCA II (Table 1).
These activity data can be rationalized taking into consideration the amino acid sequence of this enzyme, which has been aligned with that of other $\alpha$-CAs, such as the human isoform hCA II and the bacterial one SspCA (from S. yellowstonense) (Fig. 1). It may be observed that similar to the other investigated members of the $\alpha-C A$, SazCA has the conserved three His ligands which coordinate the $\mathrm{Zn}$ (II) ion crucial for catalysis (His94, 96 and 119, hCA I numbering system). The proton shuttle residue (His64) which assists the rate-determining step of the catalytic cycle, that is, the transfer of a proton from the water coordinated to the $\mathrm{Zn}$ (II) ion as the fourth ligand to the environment, with formation of the zinc hydroxide, nucleophilic species of the enzyme is also conserved. SazCA contains also the conserved gate-keeping residues (Glu106 and Thr199) which orientate the substrate for catalysis, and are also involved in the binding of inhibitors, similar to the other $\alpha$-CAs discussed here. ${ }^{1,2,5-8}$ All these residues are in fact conserved in all these $\alpha$-CAs of mammalian or bacterial origin. Intriguing was the absence of four amino acid in the primary sequence of the bacterial $\alpha$-CAs (Fig. 1, indicated as A, B, C and D). IT ha been reported that deletion of such polypeptide loops determines an increase of the protein stability in thermophilic enzymes, reducing the conformational entropy of the molecules at elevated temperatures. ${ }^{17}$

In Figure 2, a phylogenetic analysis of SazCA is shown, comparing it to the orthologous enzymes present in bacteria (SspCA from S. yellowstonense; ${ }^{1}$ hpaCA from Helicobacter pylori, ${ }^{18}$ NgCA from Neisseria gonorrhea, ${ }^{19}$ and TcruCA from Thiomicrospira crunoge$n a),{ }^{12}$ fungi (Aspergillus orizae AoCA ${ }^{20}$ corals (STPCA and STPCA2

Table 1

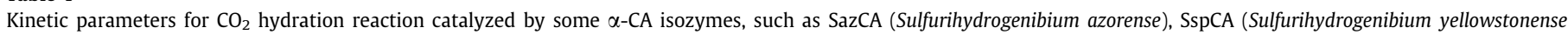

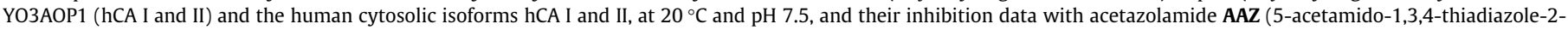
sulfonamide), a clinically used drug

\begin{tabular}{|c|c|c|c|c|c|}
\hline Enzyme & Activity level & $k_{\text {cat }}\left(\mathrm{s}^{-1}\right)$ & $K_{\mathrm{m}}(\mathrm{mM})$ & $k_{\text {cat }} / K_{\mathrm{m}}\left(\mathrm{M}^{-1} \times \mathrm{s}^{-1}\right)$ & $K_{\mathrm{I}}$ (acetazolamide) (nM) \\
\hline SazCA ${ }^{a}$ & Highest & $4.4 \times 10^{6}$ & 12.5 & $3.5 \times 10^{8}$ & 0.9 \\
\hline SspCA ${ }^{b}$ & High & $9.35 \times 10^{5}$ & 8.4 & $1.1 \times 10^{8}$ & 4.5 \\
\hline hCA I ${ }^{\mathrm{b}}$ & Medium & $2.00 \times 10^{5}$ & 4.0 & $5.0 \times 10^{7}$ & 250 \\
\hline hCA II ${ }^{\mathrm{b}}$ & Very high & $1.40 \times 10^{6}$ & 9.3 & $1.5 \times 10^{8}$ & 12 \\
\hline
\end{tabular}

a Recombinant enzyme, stopped flow $\mathrm{CO}_{2}$ hydrase assay method, this work.

b Recombinant bacterial enzyme, from Ref. 1.

hCAII
SspCA
SazCA
hCA_II
SspCA
SazCA

hCA_II
SspCA
SazCA

hCA_II
SspCA
SazCA

hCA_II
SspCA
SazCA

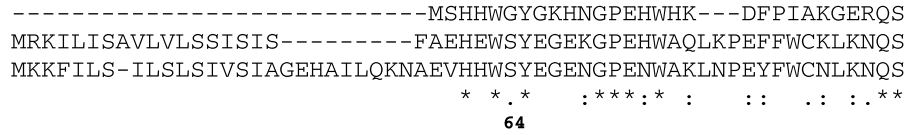
PVDIDTHTAKYDPSLKPLSVSYDOATSLRILNNGHAFNVEFDDSODKAVLKGGPLDGTYR PINIDKKY-KVKANLPKLNLYYKTAKESEVVNNGHTIQINIKEDNTLNY-----LGEKYQ PVDISDNY-KVHAKLEKLHINYNKAVNPEIVNNGHTIQVNVLEDFKLNI-----KGKEYH

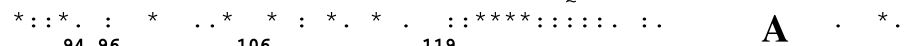

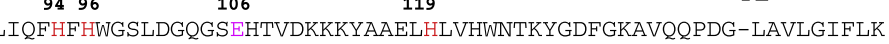
LKQFHFH-----TPSEHTIEKKSYPLEIHFVH---------KTEDGKILVVGVMAK LKQFHFH-----APSEHTVNGKYYPLEMHLVH----------KDKDGNIAVIGVFFK

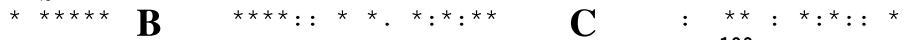
VGSAKPGLQKVVDVLDSIKTKGKSADFTNFAARGLLPESLDYWTYPGSLTTPPLLECVTW LGKTNKELDKILNV--APAEEGEKILDKNLNLNNLI PKDKRYMTYSGSLTTPPCTEGVRW EGKANPELDKVFKN--ALKEEGSKVFDGS ININALLPPVKNYYTYSGSLTTPPCTEGVLW

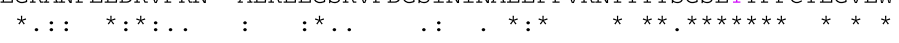

IVLKEPISVSSEQVLKFRKLNFNGEGEPEELMVDNWRPAQPLKNRQIKASFK IVLKKPISISKQQLEKLKSV--------MVNPNNRPVQEINSRWI IEGFIVLKQPITASKQQIELFKSI---------MKHNNNRPTQPINSRYILESN${ }^{* * * *}:{ }^{*}: *^{*} .{ }^{*}: \quad: \ldots: \quad \mathbf{D}:{ }^{*},{ }^{*} . *^{*}: .^{*}{ }^{*}$.

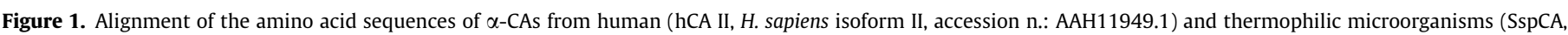

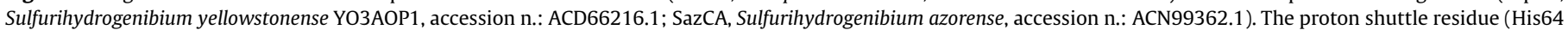

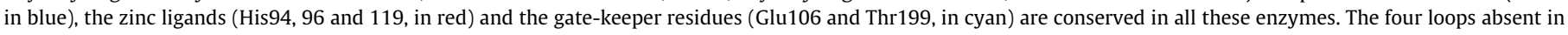

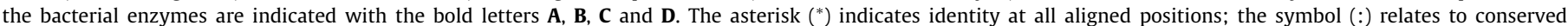

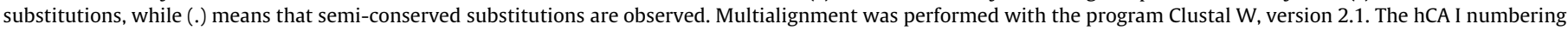
system was used. 




Figure 2. Phylogenetic trees of the sequences of the $\alpha$-CAs from different sources. The tree was constructed using the program PhyML 3.0. Branch support values are reported at branch points. Legend: $\mathrm{CAH}-4 \mathrm{a}$, Caenorhabditis elegans isoform a (Accession n.: NP_510265 STPCA); CAH-4b, Caenorhabditis elegans isoform b (Accession n.: NP_510264); AoCA, Aspergillus oryzae, (Accession n.: EIT75832.1); CrCA, Chlamydomonas reinhhardtii (Accesion n.: BAA14232.2); DsCA, Dunaliella salina (Accesion n.: AAC49378.1); STPCA, Stylophora pistillata (Accession n.: ACA53457.1); STPCA-2, Stylophora pistillata, (Accession n.: ACE95141.1); hCAI, Homo sapiens, isoform I (Accession n.: NP_001158302.1); hCAII, Homo sapiens, isoform II (Accession n.: AAH11949.1); TcruCA, Thiomicrospira crunogena XCL-2 (Accession n.: ABB42137.2); SspCA, Sulfurihydrogenibium yellowstonense YO3AOP1 (Accession n.: ACD66216.1); hpaCA, Helicobacter pylori J99 CA (Accession n.: NP_223829.1); NgCA, Neisseria gonorrhoeae CA (Accession number: CAA72038.1); SazCA, Sulfurihydrogenibium azorense (Accession n.: ACN99362.1).

from Stylophora pistillata), ${ }^{21,22}$ nematodes (CAH-4b and CAH-4a from the worm Caenorhabditis elegans), ${ }^{23}$ green algae (Dunalliella salina, DsCA and Chlamydomonas reinhardii, CrCA), ${ }^{24,25}$ and mammals (the human isoforms hCA I and II). The bacterial $\alpha$-CAs are phylogenetically more close to the mammalian and coral clade than the group including the nematode (CAH-4a and $4 \mathrm{~b}$ ), fungal (AoCA) and algal (CrCA and DsCA) $\alpha$-CAs (Fig. 1). The evolution of the 'extremo- $\alpha$-CA' is marked by several gene duplication events leading to the segregation of the mesophilic and the thermophilic $\alpha$-CAs. In particular, the extremo-a-CAs (SspCA, SazCA and TcruCA) are grouped in a clade resulting from the duplication of an ancestral gene that gave also origin to the bacterial mesophilic clade (NgCA and hpaCA).

In Table 2 we report SazCA inhibition data with a rather wide range of simple and complex inorganic anions as well as several small molecules observed earlier to act as CA inhibitors (CAIs) against other such enzymes. ${ }^{13-16}$ The analogous data for the inhibition of SspCA and of the two widespread and highly investigated human isoforms hCA I and II are also provided for comparison reasons, as they were reported earlier by our group. ${ }^{1,2}$ The inhibition profile of SazCA is distinct of those of other $\alpha$-CAs, as follows:

(i) The anions with the smallest propensity to coordinate metal ions, perchlorate and tetrafluroborate, were not inhibitors of SazCA up to concentrations of $200 \mathrm{mM}$. The same is true for the human isoforms hCA I and II as well as the bacterial one SspCA.

(ii) Several other anions, such as bicarbonate, carbonate, sulfate and peroxydisulfate were also weak inhibitors of SazCA, with inhibition constants in the range of $7.6-32.9 \mathrm{mM}$. It is interesting to note that except for sulfate, which was inhibitory, these anions were also weak inhibitors of the related enzyme SspCA investigated earlier. ${ }^{2 a}$ It should be noted that the weak affinity of SazCA for bicarbonate and carbonate might be a positive feature for its potential biotechnological application in the $\mathrm{CO}_{2}$ capture processes, since the enzyme is not appreciably inhibited in the presence of rather high concentrations of the two anions (Table 2).

(iii) A rather large number among the investigated anions were submillimolar SazCA inhibitors, with $K_{\mathrm{I}} \mathrm{S}$ in the range of 0.34$0.98 \mathrm{mM}$. They include the halides, (thio)cyanate, cyanide, azide,
Table 2

Inhibition constants of anionic inhibitors against $\alpha$-CA isozymes derived from human (hCA I and II), and the bacterial enzymes SspCA and SazCA, at $20^{\circ} \mathrm{C}$ by a stopped flow $\mathrm{CO}_{2}$ hydrase assay ${ }^{18}$

\begin{tabular}{|c|c|c|c|c|}
\hline \multirow[t]{2}{*}{ Inhibitor $^{\mathrm{a}}$} & \multicolumn{4}{|c|}{$K_{\mathrm{I}}[\mathrm{mM}]^{\mathrm{b}}$} \\
\hline & $\mathrm{hCA} \mathrm{I}^{\mathrm{c}}$ & hCA II ${ }^{\mathrm{c}}$ & $\mathrm{SspCA}^{\mathrm{d}}$ & $\mathrm{SazCA}^{\mathrm{e}}$ \\
\hline $\mathrm{F}^{-}$ & $>300$ & $>300$ & 41.7 & 0.98 \\
\hline $\mathrm{Cl}^{-}$ & 6 & 200 & 8.30 & 0.85 \\
\hline $\mathrm{Br}^{-}$ & 4 & 63 & 49.0 & 0.94 \\
\hline $\mathrm{I}^{-}$ & 0.3 & 26 & 0.86 & 0.87 \\
\hline $\mathrm{CNO}^{-}$ & 0.0007 & 0.03 & 0.80 & 0.47 \\
\hline $\mathrm{SCN}^{-}$ & 0.2 & 1.60 & 0.71 & 0.58 \\
\hline $\mathrm{CN}^{-}$ & 0.0005 & 0.02 & 0.79 & 0.40 \\
\hline $\mathrm{N}_{3}^{-}$ & 0.0012 & 1.51 & 0.49 & 0.34 \\
\hline $\mathrm{HCO}_{3}{ }^{-}$ & 12 & 85 & 33.2 & 15.7 \\
\hline $\mathrm{CO}_{3}{ }^{2-}$ & 15 & 73 & 39.3 & 7.60 \\
\hline $\mathrm{NO}_{3}^{-}$ & 7 & 35 & 0.86 & 0.76 \\
\hline $\mathrm{NO}_{2}^{-}$ & 8.4 & 63 & 0.48 & 0.58 \\
\hline $\mathrm{HS}^{-}$ & 0.0006 & 0.04 & 0.58 & 0.38 \\
\hline $\mathrm{HSO}_{3}{ }^{-}$ & 18 & 89 & 21.1 & 0.95 \\
\hline $\mathrm{SnO}_{3}{ }^{2-}$ & 0.57 & 0.83 & 0.52 & 0.76 \\
\hline $\mathrm{SeO}_{4}{ }^{2-}$ & 118 & 112 & 0.57 & 0.51 \\
\hline $\mathrm{TeO}_{4}{ }^{2-}$ & 0.66 & 0.92 & 0.53 & 0.41 \\
\hline $\mathrm{P}_{2} \mathrm{O}_{7}^{4-}$ & 25.77 & 48.50 & 0.69 & 0.66 \\
\hline $\mathrm{V}_{2} \mathrm{O}_{7}^{4-}$ & 0.54 & 0.57 & 0.66 & 0.35 \\
\hline $\mathrm{B}_{4} \mathrm{O}_{7}{ }^{2-}$ & 0.64 & 0.95 & 0.67 & 0.49 \\
\hline $\mathrm{ReO}_{4}^{-}$ & 0.110 & 0.75 & 0.80 & 0.73 \\
\hline $\mathrm{RuO}_{4}^{-}$ & 0.101 & 0.69 & 0.69 & 0.52 \\
\hline $\mathrm{S}_{2} \mathrm{O}_{8}{ }^{2-}$ & 0.107 & 0.084 & 84.6 & 32.9 \\
\hline $\mathrm{SeCN}^{-}$ & 0.085 & 0.086 & 0.07 & 0.49 \\
\hline $\mathrm{CS}_{3}{ }^{2-}$ & 0.0087 & 0.0088 & 0.06 & 0.039 \\
\hline $\mathrm{Et}_{2} \mathrm{NCS}_{2}{ }^{-}$ & 0.79 & 3.1 & 0.004 & 0.003 \\
\hline $\mathrm{SO}_{4}^{2-}$ & 63 & $>200$ & 0.82 & 10.0 \\
\hline $\mathrm{ClO}_{4}^{-}$ & $>200$ & $>200$ & $>200$ & $>200$ \\
\hline $\mathrm{BF}_{4}^{-}$ & $>200$ & $>200$ & $>200$ & $>200$ \\
\hline $\mathrm{FSO}_{3}{ }^{-}$ & 0.79 & 0.46 & 0.73 & 0.65 \\
\hline $\mathrm{NH}\left(\mathrm{SO}_{3}\right)_{2}{ }^{2-}$ & 0.31 & 0.76 & 0.75 & 0.52 \\
\hline $\mathrm{H}_{2} \mathrm{NSO}_{2} \mathrm{NH}_{2}$ & 0.31 & 1.13 & 0.009 & 0.004 \\
\hline $\mathrm{H}_{2} \mathrm{NSO}_{3} \mathrm{H}$ & 0.021 & 0.39 & 0.042 & 0.005 \\
\hline $\mathrm{Ph}-\mathrm{B}(\mathrm{OH})_{2}$ & 58.6 & 23.1 & 0.041 & 0.007 \\
\hline $\mathrm{Ph}-\mathrm{AsO}_{3} \mathrm{H}_{2}$ & 31.7 & 49.2 & 0.005 & 0.008 \\
\hline
\end{tabular}

a As sodium salt.

b Errors were in the range of $3-5 \%$ of the reported values, from three different assays.

c From Ref.13.

d From Ref. 2a.

e This work.

nitrate, nitrite, hydrogensulfide, stannate, selenate, tellurate, diphosphate, divanadate, tetraborate, perrhenate, perruthenate, selenocyanide, fluorosulfate, and iminodisulfonate (Table 2). It is rather probable that most of these anions can inhibit SazCA similar to the human isoforms hCA I and II, by coordinating to the $\mathrm{Zn}(\mathrm{II})$ ion from the enzyme active site. ${ }^{13}$ Indeed, there are many X-ray crystal structures of various anions bound to the human isoforms, which as seen from data of Table 2, are inhibited more or less in the same range by many of these anions, as SazCA. However, there are some important differences between SazCA and SspCA inhibition profiles with anions such as fluoride, chloride, bromide, and hydrogensulfite, withe the first enzyme being inhibited considerably more by these species, compared to the second one. A special mention should be also made regarding hydrogensulfide which is a relatively inefficient SspCA and SazCA inhibitor $\left(K_{\mathrm{I}} \mathrm{S}\right.$ of 0.38 $0.58 \mathrm{mM}$ ) whereas this anion is much more inhibitory against hCA I and II ( $K_{\mathrm{I}} \mathrm{S}$ of $0.6-40 \mathrm{M}$, Table 2 ). Thus, there is a difference of several orders of magnitude in the sensitivity of the bacterial versus the mammalian isoforms for this anion. This is probably due to the fact that the bacteria expressing SspCA and SazCA live in environments rich in hydrogen sulfide. ${ }^{2,3}$

(iv) The best anion inhibitors of SazCA were trithiocarbonate, diethylditiocarbamate, sulfamide, sulfamate, phenylboronic acid and phenylarsonic acid, which showed a low micromolar affinity 
for this enzyme, with $K_{\mathrm{I}} \mathrm{S}$ in the range of 3.0-39 M. Trithiocarbonate and diethyldithiocarbamate were recently shown to lead to highly potent inhibitors directed against many $\alpha$ - or $\beta$-CAs, and some Xray crystal structures also revealed their binding mode, which is achieved by coordination to the metal ion via a sulfur, negatively charged atom. ${ }^{26}$ It is conceivable that a similar binding mode is achieved also within the SazCA active site. Sulfamide and sulfamate also coordinate (via a ionized nitrogen atom) to the $\mathrm{Zn}(\mathrm{II})$ ion within the hCA II active site, ${ }^{27}$ and probably the same inhibition mechanism is valid against this bacterial enzyme.

In conclusion, we investigated an $\alpha$-CA from the thermophilic bacterium Sulfurihydrogenibium azorense, which is the catalytically most active enzyme known to date for the physiological reaction of $\mathrm{CO}_{2}$ hydration to bicarbonate and protons. This highly thermostable enzyme was investigated for its inhibition profile with inorganic simple/complex anions. The best inhibition was observed with trithiocarbonate, diethyldithiocarbamate, sulfamide, sulfamate, phenylboronic, and phenylarsonic acid, which showed inhibition constants in the range of 3-39 M. As SazCA is very stable at high temperatures (being an 'extremo-CA') and very effective as a catalyst for $\mathrm{CO}_{2}$ hydration, the inhibition studies reported here may be crucial for designing biotechnological applications for this enzyme, for example for $\mathrm{CO}_{2}$ capture processes.

\section{Acknowledgments}

This work was financed in part by an FP7 EU project (Metoxia, to CTS and AS) and and grant from the 'Accordo di Programma, CNR-MSE, PAR 2009-2010'.

\section{References and notes}

1. Capasso, C. De Luca, V.; Carginale, V.; Rossi, M. J. Enzyme Inhib. Med. Chem. in press, 27. http://dx.doi.org/10.3109/14756366.2012.703185

2. (a) De Luca, V.; Vullo, D.; Scozzafava, A.; Rossi, M.; Supuran, C. T.; Capasso, C Bioorg. Med. Chem. Lett. 2012, 22, 5630; (b) Vullo, D.; De Luca, V.; Scozzafava, A.; Carginale, V.; Rossi, M.; Supuran, C. T.; Capasso, C. Bioorg. Med. Chem. in press. http://dx.doi.org/10.1016/j.bmc.2012.07.024.; (c) Vullo, D.; De Luca, V.; Scozzafava, A.; Carginale, V.; Rossi, M.; Supuran, C. T.; Capasso, C. Bioorg. Med. Chem. Lett 2012, 22, 6324.

3. (a) Yang, T.; Lyons, S.; Aguilar, C.; Cuhel, R.; Teske, A. Front. Microbiol. 2011, 2 130; (b) Kubo, K.; Knittel, K.; Amann, R.; Fukui, M.; Matsuura, K. Syst. Appl. Microbiol. 2011, 34, 293.

4. (a) Reysenbach, A. L.; Hamamura, N.; Podar, M.; Griffiths, E.; Ferreira, S.; Hochstein, R.; Heidelberg, J.; Johnson, J.; Mead, D.; Pohorille, A.; Sarmiento, M. Schweighofer, K.; Seshadri, R.; Voytek, M. A. J. Bacteriol. 1992, 2009, 191; (b) Nakagawa, S.; Shtaih, Z.; Banta, A.; Beveridge, T. J.; Sako, Y.; Reysenbach, A. L. Int. J. Syst. Evol. Microbiol. 2005, 55, 2263; c) Aguiar, P.; Beveridge, T. J.; Reysenbach, A. L. Int. J. Syst. Evol. Microbiol. 2004, 54, 33; d) Takai, K.; Kobayashi, H.; Nealson, K. H.; Horikoshi, K. Int. J. Syst. Evol. Microbiol. 2003, 53, 823.

5. (a) Tu, C.; Tripp, B. C.; Ferry, J. G.; Silverman, D. N. J. Am. Chem. Soc. 2001, 123 , 5861; (b) Moya, A.; Tambutté, S.; Bertucci, A.; Tambutté, E.; Lotto, S.; Vullo, D.; Supuran, C. T.; Allemand, D.; Zoccola, D. J. Biol. Chem. 2008, 283, 25475; (c) Domsic, J. F.; Avvaru, B. S.; Kim, C. U.; Gruner, S. M.; Agbandje-McKenna, M. Silverman, D. N.; McKenna, R. J. Biol. Chem. 2008, 283, 30766.

6. (a) Supuran, C. T. Nat. Rev. Drug Disc. 2008, 7, 168; (b) Supuran, C. T. Bioorg. Med. Chem. Lett. 2010, 20, 3467; (c) Supuran, C. T. Curr. Pharm. Des. 2010, 16, 3233; (d) Neri, D.; Supuran, C. T. Nat. Rev. Drug Disc. 2011, 10, 767.

7. (a) Xu, Y.; Feng, L.; Jeffrey, P. D.; Shi, Y.; Morel, F. M. Nature 2008, 452, 56; (b) Viparelli, F.; Monti, S. M.; De Simone, G.; Innocenti, A.; Scozzafava, A.; Xu, Y.; Morel, F. M. M.; Supuran, C. T. Bioorg. Med. Chem. Lett. 2010, 20, 4745; (c) Alterio, V.; Langella, E.; Viparelli, F.; Vullo, D.; Ascione, G.; Dathan, N. A.; Morel, F. M. M.; Supuran, C. T.; De Simone, G.; Monti, S. M. Biochimie 2012, 94, 1232

8. (a) Supuran, C. T.; Scozzafava, A.; Casini, A. Med. Res. Rev. 2003, 23, 146; (b) Pastorekova, S.; Parkkila, S.; Pastorek, J.; Supuran, C. T. J. Enzyme Inhib. Med. Chem. 2004, 19, 199.

9. (a) Huessemann, M. H. Mar. Ecol. Prog. Ser. 2008, 364, 243; (b) Greer, T.; Bedelbayev, A.; Igreja, J. M.; Gomes, J. F.; Lie, B. Environ. Technol. 2010, 31, 107.
10. Bond, G. M.; Stringer, J.; Brandvold, D. K.; Simsek, F. A.; Medina, M. G.; Egeland, G. Energy Fuels 2001, 15, 309.

11. Fisher, Z.; Boone, C. D.; Biswas, S. M.; Venkatakrishnan, B.; Aggarwal, M.; Tu, C.; Agbandje-McKenna, M.; Silverman, D.; McKenna, R. Protein Eng. Des. Sel. 2012, $25,347$.

12. Díaz Torres, N.; González, G.; Biswas, S.; Scott, K. M.; McKenna, R. Acta Crystallogr., Sect. F: Struct. Biol. Cryst. Commun. 2012, 68, 1064.

13. (a) Alterio, V.; Di Fiore, A.; D’Ambrosio, K.; Supuran, C. T.; De Simone, G. Chem Rev. 2012, 112, 4421; (b) De Simone, G.; Supuran, C. T. J. Inorg. Biochem. 2012 $111,117$.

14. Khalifah, R.G. J. Biol. Chem. 1971, 246, 2561. An Applied Photophysics stoppedflow instrument has been used for assaying the $\mathrm{CA}$ catalysed $\mathrm{CO}_{2}$ hydration activity. Phenol red (at a concentration of $0.2 \mathrm{mM}$ ) has been used as indicator, working at the absorbance maximum of $557 \mathrm{~nm}$, with $10-20 \mathrm{mM}$ Hepes (pH 7.5 , for $\alpha$-CAs) as buffer, and $20 \mathrm{mM} \mathrm{NaBF}_{4}$ for maintaining constant the ionic strength following the initial rates of the $\mathrm{CA}$-catalyzed $\mathrm{CO}_{2}$ hydration reaction for a period of $10-100 \mathrm{~s}$. The $\mathrm{CO}_{2}$ concentrations ranged from 1.7 to $17 \mathrm{mM}$ for the determination of the kinetic parameters and inhibition constants. For each inhibitor at least six traces of the initial $5-10 \%$ of the reaction have been used for determining the initial velocity. The uncatalyzed rates were determined in the same manner and subtracted from the total observed rates. Stock solutions of inhibitor $(10 \mathrm{mM})$ were prepared in distilled-deionized water and dilutions up to $0.01 \mathrm{nM}$ were done thereafter with the assay buffer. Inhibitor and enzyme solutions were preincubated together for $15 \mathrm{~min}$ at room temperature prior to assay, in order to allow for the formation of the E-I complex. The inhibition constants were obtained by non-linear least-squares methods using PRISM 3, whereas the kinetic parameters for the uninhibited enzymes from Lineweaver-Burk plots, as reported earlier, ${ }^{15}$ and represent the mean from at least three different determinations.

15. (a) Vullo, D.; Nishimori, I.; Scozzafava, A.; Köhler, S.; Winum, J. Y.; Supuran, C. T. Bioorg. Med. Chem. Lett. 2010, 20, 2178; (b) Kolayli, S.; Karahalil, F.; Sahin, H.; Dincer, B.; Supuran, C. T. J. Enzyme Inhib. Med. Chem. 2011, 26, 895; (c) Maresca, A.; Vullo, D.; Scozzafava, A.; Supuran, C. T. J. Enzyme Inhib. Med. Chem. in press, 27. http://dx.doi.org/10.3109/14756366.2011.649268.; (d) Innocenti, A.; Scozzafava, A.; Supuran, C. T. Bioorg. Med. Chem. Lett. 1855, 2009, 19; (e) Temperini, C.; Scozzafava, A.; Supuran, C. T. Bioorg. Med. Chem. Lett. 2010, 20, 474.

16. Competent E. coli BL21 (DE3) cells were transformed with the plasmid pET15b containing the Sulfurihydrogenibium sp gene encoding for the carbonic anhydrase and lacking the signal peptide (first 20 amino acid of the peptide sequence). Cells were grown at $37^{\circ} \mathrm{C}$ and induced with $1 \mathrm{mM}$ IPTG. After additional growth for $5 \mathrm{~h}$, the cells were harvested and disrupted by sonication at $4{ }^{\circ} \mathrm{C}$. Following centrifugation, the cell extract was heated at $90{ }^{\circ} \mathrm{C}$ for $30 \mathrm{~min}$ and centrifuged. The supernatant was loaded into His-select HF Nickel affinity gel and the protein was eluted with $250 \mathrm{mM}$ imidazole. At this stage of purification the enzyme was at least $95 \%$ pure. All the details concerning the expression and purification are described by Capasso et al. ${ }^{1}$

17. Kumar, S.; Nussinov, R. Cell Mol. Life Sci. 2001, 58, 1216.

18. (a) Nishimori, I.; Minakuchi, T.; Morimoto, K.; Sano, S.; Onishi, S.; Takeuchi, H.; Vullo, D.; Scozzafava, A.; Supuran, C. T. J. Med. Chem. 2006, 49, 2117; (b) Nishimori, I.; Minakuchi, T.; Kohsaki, T.; Onishi, S.; Takeuchi, H.; Vullo, D.; Scozzafava, A.; Supuran, C. T. Bioorg. Med. Chem. Lett. 2007, 17, 3585; (c) Nishimori, I.; Onishi, S.; Takeuchi, H.; Supuran, C. T. Curr. Pharm. Des. 2008, 14, 622.

19. (a) Adler, L.; Brundell, J.; Falkbring, S. O.; Nyman, P. O. Biochim. Biophys. Acta 1972, 284, 298; (b) Supuran, C. T. Front. Pharmacol. 2011, 2, 34.

20. Cuesta-Seijo, J. A.; Borchert, M. S.; Navarro-Poulsen, J. C.; Schnorr, K. M.; Mortensen, S. B.; Lo Leggio, L. FEBS Lett. 2011, 585, 1042

21. Bertucci, A.; Innocenti, A.; Zoccola, D.; Scozzafava, A.; Allemand, D.; Tambutté, S.; Supuran, C. T. Bioorg. Med. Chem. Lett. 2009, 19, 650.

22. Bertucci, A.; Tambutté, S.; Supuran, C. T.; Allemand, D.; Zoccola, D. Mar Biotechnol. (NY) 2011, 13, 992

23. Hall, R. A.; Vullo, D.; Innocenti, A.; Scozzafava, A.; Supuran, C. T.; Klappa, P.; Muhlschlegel, F. A. Mol. Biochem. Parasitol. 2008, 161, 140.

24. Premkumar, L.; Greenblatt, H. M.; Bageshwar, U. K.; Savchenko, T.; Gokhman, I.; Sussman, J. L.; Zamir, A. Proc Natl. Acad. Sci. U.S.A. 2005, 102, 7493.

25. Fukuzawa, H.; Fujiwara, S.; Yamamoto, Y.; Dionisio-Sese, M. L.; Miyachi, S. Proc. Natl. Acad. Sci. U.S.A. 1990, 87, 4383.

26. (a) Carta, F.; Aggarwal, M.; Maresca, A.; Scozzafava, A.; McKenna, R.; Supuran, C. T. Chem. Commun. 1868, 2012, 48; (b) Maresca, A.; Carta, F.; Vullo, D.; Supuran, C. T. J. Enzyme Inhib. Med. Chem. in press, 27. http://dx.doi.org/ 10.3109/14756366.2011.641015. (c) Monti, S. M. Maresca, A. Carta, F. De Simone, G.; Mühlschlegel, F. A.; Scozzafava, A.; Supuran, C. T. Bioorg. Med. Chem. Lett. 2012, 22, 859; (d) Carta, F.; Aggarwal, M.; Maresca, A.; Scozzafava, A.; McKenna, R.; Masini, E.; Supuran, C. T. J. Med. Chem. 2012, 55, 1721.

27. Abbate, F.; Supuran, C. T.; Scozzafava, A.; Orioli, P.; Stubbs, M.; Klebe, G. J. Med. Chem. 2002, 45, 3583 